\title{
Repensando a "aposta pela vida": para uma sociologia ambiental no século XXI
}

\section{Rethinking the "wager on life:" toward environmental sociology in the twenty-first century}

\author{
Leo Peixoto Rodrigues \\ Professor, Programas de Pós-graduação em Sociologia e em Ciência Política/Universidade Federal de Pelotas (UFPel). \\ leo.peixotto@gmail.com
}

Rafael Braz

Professor, Departamento de Sociologia e Política/UFPel. rafael-braz@hotmail.com

Camila Prates

Pós-doutoranda, Programa de Pós-graduação em Sociologia/UFPel. camilapratescs@gmail.com



LEFF, Enrique. A aposta pela vida: imaginação sociológica e imaginários sociais nos territórios ambientais do Sul. Petrópolis: Vozes. 2016. 510p.
G nrique Leff, sociólogo mexicano, pode ser considerado um dos Eprincipais intelectuais da sociologia ambiental da América Latina. É professor da Universidade Autônoma do México, foi coordenador da Rede de Formação Ambiental para América Latina e Caribe do Programa das Nações Unidas para o Meio Ambiente (Pnuma) e trabalha com problemas relacionados à construção do conhecimento e desafios da interface entre ambiente e desenvolvimento, pelo viés da sociologia ambiental.

A aposta pela vida é fruto de claro amadurecimento intelectual, propiciado não apenas pela vivência acadêmica, mas pela experiência de quem se tem confrontado intensamente com a chamada "crise ambiental mundial" e com os povos "dos territórios do Sul". A mais recente obra de Leff chegou ao Brasil pela Editora Vozes em 2016, resultado de ideias debatidas em congressos na América Latina, e cujo mote central é a busca pelas causas epistemológicas da crise ambiental.

Entretanto, apesar de o tema ultrapassar fronteiras disciplinares, Leff o ancora na sociologia, posto que para ele os problemas ambientais "remetem aos fundamentos ontológicos e epistemológicos da construção da ordem social do mundo em crise e da sociedade insustentável" (p.20).

Na "Introdução", Leff retoma o debate sobre os cânones constitutivos da Modernidade e da racionalidade, contrapondo-os à chamada pós-modernidade. O que ele traz de novo é 
a ênfase no papel das ciências sociais e da sociologia a partir da proposta (e aposta) em uma renovada epistemologia, além de demarcar o protagonismo da sociologia na questão ambiental. A "sociologia da questão ambiental", como afirma, é aquela que de forma imaginativa deslegitima as "racionalidades (epistemológicas) hegemônicas", colocando no centro a necessária "racionalidade ambiental" e sua capacidade de outridade (a inescusável alteridade) contextual/relacional.

No início da discussão sobre a crise ambiental à luz das ciências sociais, Enrique Leff retoma alguns clássicos da sociologia, para demonstrar que a disciplina nasce sob a égide de uma epistemologia de orientação analítica, que tributa ao positivismo de Comte, às visões evolucionistas e funcionalistas e às propostas teóricas de Herbert Spencer e de Émile Durkheim. Mostra também que a teoria social se tornou mais complexa e aponta autores que aportam contribuições à questão ambiental, com uma epistemologia de orientação histórica e/ou construtivista, tais como Michel Foucault, Berger e Luckmann, e Pierre Bourdieu.

Na sequência da discussão conceitual, Leff faz uma "genealogia disciplinar" dos vários esquemas teóricos que desaguaram na sociologia ambiental, a qual teve como ponto de partida outra abordagem sobre a crise ambiental. Isto significa dizer que a questão ambiental emerge de duas crises sinergéticas: a do conhecimento racional moderno e a dos modos de apropriação do mundo.

As diferentes linhas analisadas - realismo; construtivismo; construtivismo discursivo; sociologia do risco; modernização reflexiva; modernização ecológica; teoria dos fluxos ambientais; teoria da complexidade global; teoria da termodinâmica e outras - surgem como respostas aos desafios epistemológicos impostos pela crise ambiental. Entretanto, segundo Leff, elas compartilham duas grandes falhas: não propõem uma reflexão sobre os princípios da Modernidade e não correlacionam a questão ambiental e a crise civilizatória com a crise do "conhecimento moderno" (Floriani, 2010, p.57).

Frente a isso, o autor propõe a sociologia ambiental crítica, para questionar os pressupostos da razão tecnoeconômica e da capitalização da natureza, argumentando que a imaginação sociológica pode contribuir para a construção de sociedades "realmente" sustentáveis por serem baseadas nos imaginários sociais dos povos da terra. Como desdobramento dessa proposta surgiu a ecologia política, que tem no fenômeno do poder seu eixo teórico fundamental. Essa vertente, para Leff, define seu campo de atuação no conflito social e nas estratégias de poder que permeiam o desafio de construção de diferentes alternativas de sustentabilidade. A orientação teórico-epistemológica da ecologia política se direciona aos processos e práticas sociais, políticas e culturais de reapropriação da natureza e da vida, valorizando a diversidade sociocultural e propondo um diálogo de saberes.

O objetivo, na parte final do livro, é mostrar ao leitor que o diálogo entre o saber científico e os demais saberes amplia as possibilidades de emergência de uma racionalidade ambiental. O ponto de partida para atingi-la é a análise dos imaginários sociais dos povos da terra (seringueiros, ribeirinhos, indígenas, pequenos agricultores, pescadores, entre outros) como processos resultantes da interação (muitas vezes forçada) com a racionalidade tecnocientífica moderna. Os imaginários sociais remetem a uma estrutura geral da compreensão do mundo; são processos nos quais está inscrito o habitus (modos de pensar e agir) instituído dentro de uma ordem cultural com condições ambientais delimitadas. 
Contudo, para que o diálogo seja possível, é preciso praticar uma episteme desconstrucionista da ciência à sociologia ambiental. Dessa forma, a sociologia ambiental crítica é chamada para participar da construção da racionalidade ambiental ao direcionar a reflexão sobre o "ser cultural" que habita os povos da terra, seu potencial de "outridade" e a pensar estratégias de diálogo nos momentos de conflito pelo território, porque em cada território se constituem as formas objetivas de vida de cada povo da terra. Como efeito, a sociologia ambiental sustenta a legitimidade de novos direitos culturais para a reapropriação da natureza.

Leff argumenta que por meio do movimento socioambiental, nascido na América Latina, os imaginários da sustentabilidade conquistam vitórias significativas no acesso ao território, como os casos dos seringueiros no Brasil, da reserva de pesca no rio Amazonas, das comunidades negras na Colômbia e do manejo florestal comunitário no México. Essas conquistas ocorrem pela atuação política de resistência e de luta pela reapropriação cultural da natureza. Trata-se de um movimento que nasce para justificar e legitimar os meios de vida e ganha fôlego no campo jurídico com a emergência de leis (décadas de 1980, 1990) que regulam os direitos dos povos e do ambiente, firmados nas novas constituições de países como Bolívia, Equador e Brasil.

As ações sociais orientadas pela racionalidade ambiental abrem caminho para a sustentabilidade da vida. Contudo, não se trata de adotar modelos prontos, buscar o consenso entre os diferentes modos de vida e espalhá-lo pelo planeta; ao contrário, a sustentabilidade dos povos torna-se dependente de estratégias de sobrevivência adotadas por culturas distintas frente à constante ameaça da destruição dos seus meios de vida. A ideia da "aposta pela vida" remete a uma nova concepção social e epistêmica resultante do conflito entre proposições - a moderna, desenvolvimentista, e a dos povos da terra - e que encontra aplicações bemsucedidas (demonstradas no capítulo 6) na América Latina. A "aposta pela vida" significa desenvolver um trabalho metafísico, epistemológico e ontológico capaz de dar esperança e de encontrar alternativas para uma vida sustentável.

Para concluir, podemos questionar, nas propostas de Enrique Leff, a capacidade efetiva empírica, portanto - de a ecologia política fazer valer seus postulados e redimensionar o equilíbrio perante o domínio da Modernidade.

Há, ainda, duas questões que são pouco exploradas pelo autor: (1) a presença do Estado e das políticas públicas no corpo teórico da ecologia política, pensando a importância ou as limitações do poder institucional e (2) a falta de articulação teórico-metodológica com os movimentos sociais; nesse sentido, o autor não deixa claro de que forma se estabeleceria ou qual seria a colaboração recíproca entre a ação social organizada e o aparato conceitual da sociologia ambiental crítica.

Mas, para além dessas ausências, as propostas demonstram a importância da contribuição teórico-epistemológica de Enrique Leff para as ciências e para demais saberes: buscar novas alternativas para antigos problemas e para os desafios contemporâneos.

\section{REFERÊNCIA}

FLORIANI, Dimas.

Complexidade e epistemologia ambiental em processos socioculturais globais e locais.

Interthesis, v.7, n.2, p.45-64. 2010. 